\title{
Toponymic Landscape of Central Yakutia: Etymological Analysis of Geographical Names
}

\author{
Liudmila S. Zamorshchikova, Irena S. Khokholova, \\ Anna N. Ikonnikova, Marianna V. Samsonova \\ and Viktoria V. Lebedeva* \\ M.K. Ammosov North-Eastern Federal University \\ 58 Belinsky Str., Yakutsk, 677000, Russia
}

Received 07.11.2018, received in revised form 18.12.2018, accepted 25.12.2018

The article focuses on the attempts of reconstructing the process of exploration of Central Yakutia on the example of the Khangalassky region in different time periods and by various tribes. As a result, the etymological analysis of toponyms of the territory under research allowed to reveal several layers of ethnic impact, as well as traces left by different ethnic groups in the course of exploration of the territory.

Modern geographical sciences (human geography in particular) demonstrate interest in the nature of relations between humans and environment, and the problems of landscape ontology as a source of a wide range of socio-humanistic knowledge. Moreover, the issues of etymology of toponyms in the Yakut language have not been studied thoroughly, although it is a factor that reveals layers of knowledge on the history of peoples who have established long-term contacts with one another; problem of language and culture of the peoples or tribes who have influenced the formation of the Yakut language on the one hand, and dialect characteristics within a single language on the other, in terms of naming the same geographical objects.

The objective of the given research is to identify the etymological element of Yakutia's toponyms in order to reconstruct the historical past of Central Yakutia's exploration, and to determine the types of landscape's identification by various ethnic groups in formation of toponyms.

The leading method in analyzing the given problem is a comparative method based on identification of the toponyms' etymological component, as well as the method of statistical processing of the quantitative results of the analysis. More than 300 toponyms have been studied on the material of the toponymic base of Central Yakutia's Khangalassky region. The etymology of toponyms is studied on the basis of dictionary definitions and the material provided by informants.

The analysis resulted in identification of etymological components in Central Yakutia's toponyms. The Khangalassky region was selected for the analysis of toponyms due to the historical factor in the first place. The Yakuts as an ethnic group had settled in the basin of

(C) Siberian Federal University. All rights reserved

* Corresponding author E-mail address: 1szam@mail.ru; iskhokholova@mail.ru; ayelovskaya@mail.ru; efimarianne@mail.ru; levik93@inbox.ru

This work is licensed under a Creative Commons Attribution-NonCommercial 4.0 International License (CC BY-NC 4.0). 
Middle Lena, in the valleys of Erkeni and Samartai. The final formation of the Sakha people occurs as a result of the mixture of outsider Turkic tribes with local paleoasiatic family groups, as well as with outsider Mongol-speaking Khori and Tungus tribes. The etymological and semantic components of toponyms show, that the toponymy of the Khangalassky region is marked by the most ancient layer in Yakutia's toponymic formation. The toponyms of the Khangalassky region have been greatly influenced by the Lena river, as well as adjacent rivers and creeks the names of which could be found in the Evenki, the Mongol, and the Turkic linguistic and cultural layers. In the toponymic formation based on the Yakut language one can observe a layer of Mongol toponyms which had appeared before the Turkic toponymic layer. Traces of Tungus-Manchurian tribes of the earliest layer could still be found among the names of small rivers and creeks, since the tribes had been wandering in order to hunt while using large objects as landmarks. The Russian etymological layer is considered to be the most recent one, connected with the territorial exploration by Russian explorers and farmers who settled on the territory of the Khangalassky region, and the post tract which linked the Yakut region to the Russian Empire during the reign of Peter I and Catherine II.

The analysis shows the gradual nature of toponymic formation in relation to the landscape. It allows systematizing the origins of toponyms in both historical and linguistic contexts. Materials presented in the article could also be of use for linguists, historians, cultural study specialists, and geographers.

Keywords: landscape, toponyms, territorial explorations, culture, etymology, ethnic and language contacts, history and origin of place names.

This article is written within the framework of the project No. 15-18-20047 "Landscape ontology: semantics, semiotics, and geographic modeling” (2015-2017) supported by the Russian Science Foundation.

Research area: culturology.

Citation: Zamorshchikova, L.S., Khokholova, I.S., Ikonnikova, A.N., Samsonova, M.V., Lebedeva, V.V. (2018). Toponymic landscape of Central Yakutia: etymological analysis of geographical names. J. Sib. Fed. Univ. Humanit. soc. sci. DOI: 10.17516/1997-1370-0363.

\section{Introduction}

The issues of human exploration of territories, forms of conceptualizing the natural objects, phenomena, and events linked to certain landscapes have been analyzed in the frame of RSF project No. 15-18-20047 "Landscape onthology: semantics, semiotics, and geographic modeling" (2015-2017). The exploration of the vast territory of Yakutia with its variety of landscapes by the indigenous peoples occurred in different historical periods. In the course of this exploration each ethnic group while adjusting to surrounding landscape, occupied a certain niche thus avoiding competition: each group occupied their own ethno-cultural landscape. Yakut cattle-breeders lived in the alases and valleys between the rivers. Tungus-speaking tribes who lived by reindeerbreeding inhabited the mountain-taiga area. Unlike the Evens and the Evenks, the 
reindeer-breeding Chukchis occupied the tundra areas. The Yukagirs who mainly focused on fishing lived in the valley of the Kolyma river. Thus, each ethnic group inhabiting the region had come up with their own system of geographical terms. Their semantics was determined not only by landscape, but also by their lifestyle and types of activities. Linguistic contacts have also played an important role in forming the geographical vocabulary in various languages.

Such great geographers as P.P. Semyonov-Tyan-Shansky and L.S. Berg had contributed greatly to the establishment of modern Russian toponymy. Over different time periods, the issues of toponymy were considered by such authors as N.V. Bubnova, V.A. Zhuchkevich, A.P. Dulzon, V.I. Lytkin, A.K. Matveev, E.M. Murzaev, V.A. Nikonov, A.I. Popov, E.M. Pospelov, D.I. Rudenko, B.A. Serebrennikov, A.V. Superanskaya. The ethno-linguistic approach is presented in the works by A.S. Gerd, N.I. Tolstoy, E.L. Berezovich. The works by V.V. Kornev represent cognitive and functional approaches. A particular branch of cultural geography focuses on developing the ideas of cultural (and humanistic) geography (Yu.A. Vvedenin, R.F. Turovsky, V.L. Kagansky, V.N. Kalutskov, A.G. Druzhinin, D.N. Zamyatin, V.P. Maksakovsky, M.V. Ragulina, and others).

Tremendous contribution in the field of name study was made by K. Miller, H. Haens, A. Hermann, P. Aalto, G.J. Ramstedt, E. Chavannes, J.G. Grano, L. Basin, F. Hirth, L. Ligeti, P. Boodberg, R. Czegledy, J. Jeong, T. Osawa.

The researchers Conedera, Vassere, Neff, Meurer and Krebs considered toponyms as a reflection of subjective environment perception. The work by Calvo-Iglesias, Díaz-Varela, Méndez-Martínez and Fra-Paleo contain a three-part interpretation of toponyms: spatial location, information about the place and landscape. Remaining despite recent land use changes but also in a long-term context, the place names show a strong inertia in time (Calvo-Iglesias et al., 2012).

Geographical names are preserved over long period of time, and many retain the original naming even in the conditions of changing environment. "The metaphor of 'cultural arena' focuses on the capacity of place names to serve as sites of contest, debate, and negotiation as social groups compete for the right to name and, in the words of Don Mitchell (2008: 43), 'the power to define the meanings that are to be read into and out of the landscape" (Rose-Redwood, Alderman, Azaryahu, 2010).

As stated by G.D. Tomakhin, "onomastic vocabulary on the whole is particularly marked in terms of both national and cultural aspects. Any given toponym and anthroponym is perceived in language and culture in the context of certain associations based on certain characteristics of the object under study" (Tomakhin, 1986). 
Toponyms play an important role in the lives of people and society, since human activity is always connected with the ideas of space, or moving in space and time. By naming and emphasizing the surrounding objects, toponyms function as signs and benchmarks guiding people across space. As marked by V.F. Barashkov, "due to this function toponyms have been accompanying humankind from ancient times up to nowadays. As a result, today even within relatively small territories one can observe co-existing geographical names which appeared during different historical periods, or names linked to languages of the peoples who used to inhabit, or still inhabit the given territory". Hence, it is obvious that while performing their primary function, toponyms of any territory represent an important source of knowledge about their home territory: the peoples and languages who used to be linked to it, certain geographical characteristics both from the past and the present, the people who left a trace in the history of the given location, etc. This leads to the suggestion that geographical names are a book which holds records on the history of humankind" (Barashkov).

Nikolay Ivanovich Nadezhdin (1804-1856), a historian and an ethnographer, as well as one of the founders of historical geography in Russia, wrote: "Toponymy is the language of the earth; the earth is a book of the history of humankind recorded in a geographic nomenclature. The first page in the history should be that of a geographic map, and not only as an auxiliary tool that allows one to see the location of events, but also as a rich archive of the documents and sources". Toponymic characteristics is closely linked to the ethnic groups who used to live and live in the given territory with their own lifestyle, contacts, cultural and worldview specifics. V.L. Vasiliev noted that "Toponymic-ethnographic map could be defined as a map showing settlements along with characterizing the semantic and linguistic genesis of the given toponyms, as well as the types of settling (according to locations in the system of cultural landscape), and the time when the settlements were founded" (Vasilyev, 2006).

Toponyms help to reconstruct ancient landscapes, ancient routes, processes of territorial exploration, economic activity characteristics; to understand the ethnogenesis specifics, and ethnic compound of population, as well as many other aspects of local environment and everyday activities within a given territory in the past (Kornev, 2014). Toponyms help to identify intra- and extra-linguistic cognitive prerequisites for the emergence and functioning of intercontinental and intracontinental namesmigrants. The linguistic-cognitive focus on toponyms allows us to consider their specificity in the conceptual perspective, and to pay attention to the mental processes of the occurrence of toponymic units in the language (Urazmetova, 2018). 
While acknowledging the inter-disciplinary nature of toponymy as a science standing on the crossroads of geography, history and linguistics, V.A. Zhuchkevich defines "toponimyc landscape" as its subject. By "toponymic landscape" he means a bulk of names of rivers, lakes, lands, relief shapes, settlements, etc. that has been formed in the given territory. "A toponymic landscape is a verbal expression of a geographic landscape" (Zhuchkevich, 1968).

When studying ontological and mental existence of toponyms L.M. Dmitrieva notes, "a toponymic system as an explication of the image of the toponymic worldview, it is built on certain principles, similar to those by which the mental image of space in general is formed, and by which in the process of perception, the toponymic picture replaces and represents the ontological form of the landscape reality's existence" (Dmitrieva, 2002). Toponyms can also act as carriers of languages and can be preserved for a long time. Toponyms were used to analyze the endangered Manchu language in Northeast China (Zhu, 2018).

The study of place names of Central Yakutia allows revealing the traditional system of orientation in space and the attitude to the surrounding world through the anthropocentric worldview. "The cognitive component covers numerous aspects of cultural knowledge accumulated over centuries in this landscape territory through deciphering the semantics of the toponyms, thus revealing the historical modes in which people used to manage natural resources, engage in agriculture, find their way in space, history and cultural experience in general; and the special attitude to natural objects and sacred places" (Khokolova, Zamorshchikova, Filippova, 2018). The study of semantics and semiotics of the nomination of landscapes in the languages of indigenous peoples of the North-East of Russia provides the ability to compare different representations of the natural world, to identify the dynamics of change in the worldview and representation, and use of the surrounding landscape (Zamorshchikova, 2016).

The material of this article is represented by the linguistic database of toponyms of the Khangalassky region. It includes both officially map-registered toponyms, and the local ones that include among others the micro-toponyms collected during the field expeditions. The database includes such indicators as toponyms in their officially recognized Russian form; the native toponymic form in Yakutia's national language; historical naming of a toponym; etymology; dictionary sources; relief characteristics; types of natural objects (rivers, lakes, mountains, plots of land); and information on the flora landscape, and soil, as well as some others. 


\section{Results of the research}

The Lena river played the key role in forming the toponyms of the Khangalassky region, as well as the adjoining small rivers and creeks, the names of which could be found in linguistic-cultural layers: the Evenki, the Mongol and the Turkic.

The most ancient Tungus-Manchurian layer can be traced in the names of small rivers and creeks which characterize 1) natural and landscape peculiarities, for instance, Dyangykh is a hill or a creek located above the tundra zone, or mountains with bare rounded tops (way-finders); Siine deriving from "hii", "a thicket, a forest (thick), taiga"; Keteme from the Evenki "meadow, a glade amidst the forest"; Negyurchene from the Evenki "negur", "a wolf". 2) due to search of hunting grounds the hunters looked to large objects mainly located along the "feeding" creeks: Degiletti from "degi" (Evenki) fowl + suffixes -le, -t, -ty = approximately, "to hunt for fowl". It is possible that the area was known for the abundance of fowl; Oldokun from "olgo-mi", i.e. to dry (out), "dried-up", or "oldo", a fish, "a huge fish" + exaggerative suffix -kun. 3) qualitative features, as in Nuolla, possibly from the Evenki "nyo", which is to outrun, or from the Yakut "nuolur", meaning very soft, tender (for certain type of feathers, small feathers, down of a bird); Nachabyl from the Evenki "na", i.e. to hit the target + suffixes -cha, -vul = possibly "to start hitting the target". 4) humans and society, as in Kycha, possibly from the name of an Evenki family of Kichel of the Baikitsky region of the Krasnoyarsky District.

Results of the research of the Khangalassky region toponyms show that toponyms of the Mongol etymology render: 1) qualitative characteristics of geographical objects in relation to small rivers and creeks: Byrdzangaya from the Khalkha "birzhiy", Buryat "birzay" meaning to be uneven, rough, spotty; Kalmyk "birzhi", which is to be wrinkly, to have facial spots. The Yakut verb "byrday" means to squeeze out (as of puss, lard); Byryi-Chyna from the Khalkha, Buryat "muddy", "dark", "murky"; Buryat "silt", "clay", "swamp"; "chin" meaning trampled down, strong; Bytyrystakh from the Mongolian "bytara", which is to fall apart into small parts, to shatter (W. Rassenen); in Yakut it denotes tassels, small rocks + -taakh, a Yakut affix of possession, Dardagar from the Khalkha "dardgar", Kalmyk "dardhr" meaning hard, hardened, rough; the Khalkha "fragile"; the Buryat "dardagar" meaning huddled; extended, covered in amalgam (see dardayi-), or Khalkha “derger", Buryat “dereger”, Kalmyk "dergr”, which is dried-up and sticking out; protruding, Buryat "dagdagar", which is straggly, shaggy; clumsy, in Yakut meaning lanky, hulking, the verb "dardai" meaning to dry up while sticking out. 2) characteristics of relief; Daban from written-Mongolian "dabahan", i.e. 
the mountain; 3) sacredness; Kullaty (Kuldaty) from late Mongolian Quladu meaning "harrier (bird of prey)", Buryat "khulda", Kalmyk "khuld" meaning "harrier (bird)", bird of prey, kulda, i.e. duck-hawk (or marsh harrier), a bird of hawk family, possibly the totem animal of the Khangalass tribe (Saneev, Orlovskaya, Shevernina, 2015, 2016).

Toponyms of Turkic origin also render 1) qualitative characteristics of rivers and creeks, for example, Kurun-Yuryakh, Kurunakh originate from a single proto-form of "ku:ra", from the Turkic proto-form "kur" (dry, to dry, to dry up). The Turkic languages show the loss of vowels in auslaut. "Kurun", "kurungakh" denote a dry tree, dry wood. Kyuryulyur from Turkic “ky': Kyr.-alt. is sound imitation of a humming sound, a dull rumbling, literally, a river making a humming or rumbling noise. Kyumyuk-Yuryakh from Old Turkic "kyopik", Turkic "kyopuk", "kyobuk", "kyobik”, "gyobyuk” (foam), from "jarik yurekh" (a river, creek, foamy river water); Left Satigay from Turkic "djadjahay", which is open, Kyrgyz "zhadahay" (literally, single, unprotected); Kazakh "zhadahay", i.e. light clothing; Yakut "satahay" (literally, open, not sealed). Epithet "Left" was probably added later or translated from Yakut into Russian. 2) particular attitude expressed towards small rivers and river as a symbol of life, where there is light and future. Of special notice are names of rivers and small rivers which derive from general Turkic etymology. For example, toponym Aallaakh probably derives from: 1) "aal" from the Turkic "sal" meaning "raft", "any floating device"; "hearth"; or 2) from "aal" meaning "sacred fire", "hearth". There is no single opinion on the origin of the given word. There are several viewpoints: 1) S. Kaluzhinsky links the Yakut "aal" to the Shor "sal" ("hearth, a place where fire is set"); according to E.Z. Kazhibekov, the Shor "sal" ("hearth, a place where fire is set") is a nominal correlate of "sal" (raft). 2. According to M. Räsänen, the Lopnur "al" meaning "a spirit, malignant creature", Turkish, Crimean-Tatar, Kumyk, Kazakh originate from "aal" meaning "red” (Saneev, 2015, 2016; Tomakhin, 1986; Urazmetova, 2018; Vasilyev, 2006). We think that the etymology of the given toponym could possibly be related to both variants (as raft and hearth), since raft could be viewed as a vessel; old vessels were used as a type of hearth in which fire could be set. The given hypothesis is also supported by the etymology of the toponym Kenkeme - from Old Turkic "keng" - wide, large; Turkic "keme/kebe" (correspondence of the labial $\mathrm{m}-\mathrm{b}$ is typical of the Altay dialect) means a fire hole, a hearth dug in the ground, "kebe", "keme" is a boat, since mud oven was usually made from an old boat; also "gemi" in Turkish dialect is "raft", "boat", "piece of ice drifting on water, that could be ridden and sailed on"; in Tatar dialect "kime zhiber" means to set up fire during ice-drift. 
Toponyms of the Khangalassky region of that period had been formed on the Evenki, Mongol, and Turkic bases; they are built on the archetypical, classic type of naming; on the dialectal relation with nature and its reclamation as a strategically necessary aspect of life (Fig. 1).

The latest layers of toponyms based on the Yakut language and the Russian layer which appeared when settlements were established, show a different attitude towards the regional landscape connected with the complete exploration of the territories and their use in economic activities.

The Yakut layer in the toponymic etymology of the Khangalassky region is determined by the introduction of settlements and their activity. The left bank uplands show the prevalence of the Yakut names. Erkeeny valley is one of the centers of the origin of the Yakut people; thus mostly Yakut toponyms are found there: At-Byraan, i.e. High hill, Orto Doidu, i.e. Middle earth, Alas, i.e. a round field or a meadow in the forest, Ugus-Urasa, i.e. a large number of old Yakut homes, Byutey bytey, i.e. 1. an enclosed place without an exit; a backwoods area; 2. A fencing, an enclosure; an enclosed pasture; 3. obsolete, a fenced land-piece that was turned from communally owned to private one.

Along with that, there are settlements with Russian names: the town of Pokrovsk, founded with the arrival of the Russian Cossacks in the $17^{\text {th }}$ century. Pokrovsk is a sacral name, referring to Pokrov, i.e. the Protection of the Holy Mother of God (an Orthodox Christian celebration); Yelanka, in Russian "yelan" means an open space in the forest. River Siine (of the Evenki origin) was renamed in the Sinyaya river, when both the phonemic and semantic aspects of the name changed. When the Irkutsk-Yakutsk post tract began to function in the $18^{\text {th }}$ century, the Russian settlers founded and populated the coach stations. This is reflected in the toponyms of the area: Yam-Aryta/ Djam aryyta (the coach island). Although the word "yam" is of the Turkic origin, it was borrowed and adapted to the Russian language. "Yam" from Turkic "djam", Turkish, Uighur, Chagat "jam", i.e. "a post station, post horses". The Soviet period made an impact on the formation of the toponymy of mainly settlements: Kyhyl sulus meaning Red star, Chapayevo, the Orkjonikidze district, Pioneer laahyra, i.e. pioneer camp, and many others.

This map shows the historical processes under which the toponyms of Russian origin overlapped the ethnic area (Erkeeni valley) inhabited by the Yakuts, thus modifying the region's toponymy.

Economic activities usually depend on landscape type. Turkic, Mongol and Yakut cattle-breeders mostly settled near lakes where the alas type of economy prevailed. The 


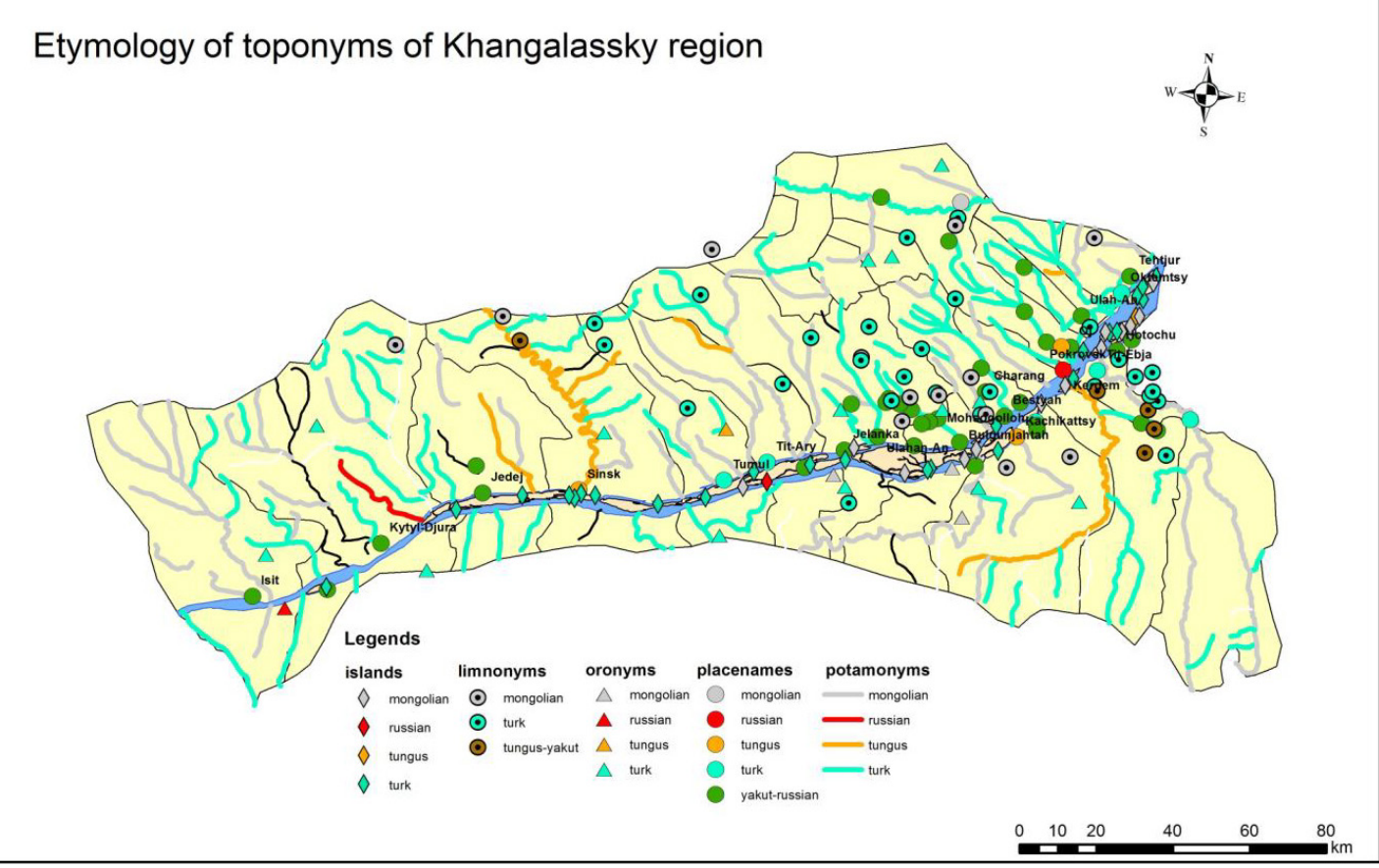

Fig. 1. Map of toponyms' etymological distribution is made in the framework of RSF project No. 15-18-20047 "Landscape ontology: semantics, semiotics, and geographic modeling” by Sebastien Gadal, Moisei Zakharov, Irena Khokholova, and Viktoriia Lebedeva

alas type is characterized by stable hay-making in places where grass is of particular nutritional value for breeding cattle and horses. All of these factors are reflected in toponymy. Names of surrounding geographical objects have Mongol, Turkic, and Yakut origin. For instance, the limnonym Kien-Tolon is likely of the Yakut origin, since "kieng" derives from Turkic "king", "keng" ("wide", "large"); "toloon" from OldTurkic "tala". The word "toloon" could be found in both Turkic and Mongol languages; Tatar "dala" meaning steppe, Buryat "tala" meaning "field", "steppe".

Names of rivers and creeks have the Turkic-Mongol origin. It is possible that they had been inhabited by the Mongol and Turkic tribes. However, this assumption is arguable, since the Yakut language derives from both languages (Turkic and Mongol), and a river or a creek could be named during the period of the formation of the Yakut ethnic group. In this case, the historical data found in regional archives appears to be the most substantial source.

Certain creeks in the region (Siine, Nyuolla, Negyuchene, and some others) are of the Evenki origin, since fishing and hunting are the basic types of the Evenk traditional economy. There are far less names of rivers and creeks of the Evenki origin than those 
of the potamonyms of the Turkic and Mongol origin. This could probably be explained by the lifestyle of the reindeer-breeding Evenks who moved from one place to another in search of feeding for reindeer, fish, or good hunt.

For the people of the Khangalassky region, islands have always been the main base for horse and cattle-breeding (the key economic branch of the region). Etymologically the majority of island names derive from the Yakut language which is obvious from the names of islands and peninsulas: Utelir from the Yakut "ytelee" meaning "to provide with food", "a place that provides the people with food stock"; Arangas-Atyr from the Yakut "yellow stallion"; or Ynakh Ary meaning "a cow island". From ancient times, the Yakuts have been using the isles as the main source of hay harvest for cattlebreeding. This could be seen in toponyms like the Yakut Uyong aryy, i.e. "a plenteous island". There are few hay-making grounds on the Lena plateau; the place is hilly and uneven. Hence, the islands with their river meadows are the ideal place for hay-making and conservation of food for long winter periods. Before the arrival of the Yakuts the territory used to be inhabited by the Tungus-speaking Evenks who were engaged in reindeer-breeding; the name of the isle Oronnookh refers to the Evenki word oron, i.e. "reindeer" with added Yakut ending ooh, which leads to the name being interpreted as "the place where reindeer live".

A toponym can also reflect certain local superstitions. The isles of the Middle Lena have always been home for the local population. Thus, the name of an isle Abaahyta suokh ("a place free from evil spirits") reflects the local beliefs, as well as certain historical events when during the collective farms' integration, people were forced to leave their homes on the isles and re-locate to the left bank of the Lena in order to join the newly-founded settlements built after unification of several post stations and island-based Yakut villages. The locals believed that the abandoned houses left on the isles became haunted. The Abaahyta suokh ("A place free from evil spirits") isle is low enough, so the water constantly washes over its surface, rendering it uninhabitable; hence, no houses were abandoned on it.

Life on the isles was comfortable for people of the region. The current of the river had contributed to creation of a special micro-climate which provided for the vegetation until late autumn protecting it from ground frosts. In spring during ice-drift and freeze-up the people lived in isolation, bearing with temporary inconveniences and without significant discomfort. Here one can trace Russian names, like Yam-Aryy (stage-coach island) which reflects the establishment of the Irkutsk - Yakutsk tract by the Russians in the $18^{\text {th }}$ century. 
The oronyms are mostly based on the Turkic-origin roots which had permeated into the Yakut language which is characteristic of the later period. For example, in the name Myachei-Sise the Yakut element "Sis" meaning "spine" derives from the Old Turkic "yim", i.e. "uplands with inhabitable valleys". The name itself has undergone both phonetical and orthographical changes. It is often used as a geographical term (metaphorically) referring to uplands, mountainous areas, or ridges. "Myachei" is possible a personal name linked to the form of land-owning among the Yakuts which finalized following the yasak reforms of the $18-19^{\text {th }}$ centuries. It is also possible, that the tukulans (sandy deserts remnant of the deserts of the Central Asia) had been named earlier, since the element "elesin" (sand) is a part of the toponym Kysyl-Elesin of the Mongol origin unlike the word "kumakh", i.e. "sand", of the Turkic origin. Mongolspeaking tribes had been among the first settlers of the Lena basin.

Overall, 350 toponyms were analyzed. Among them there are 90 oykonyms, 185 hydronyms (lakes -45 , rivers -140 ), 32 oronyms, and 43 island names.

Etymological analysis showed that the words of the Turkic origin prevail among the toponyms of the Khangalassky region making up 39.7\%. The words of the Yakut origin are numerous (13.6\%). Though it should be noted that many Yakut toponyms during the Yakut period were made from the Turkic-Mongol borrowings (e.g. KyhylElehin, where Kyhyl is Turkic, and Elehin is Mongol). Toponyms of Mongol (7.7\%), Tungus (2.8\%), and Russian (2.6\%) origin are also observed.

The etymological analysis has also shown a layer of toponyms of mixed (16.9\%) and unknown (17.1\%) origin. Among the toponyms with mixed etymology there are the toponyms formed by two words of different origin (Tiit-Aryy, where Tiit is Turkic for "larch", and Aryy is Yakut for "isle"), and word of questionable/arguable origin (Ebe from Mongol emee or from the Tatar ebi). The toponyms of unknown origin include the words the meaning of which is not known, and the origin of which is untraceable (Namsylay). Etymology of some words in this category is assumed but not confirmed by official sources (Nyokhoroy may probably come from the Yakut nyokhoy, i.e. "hunched").

It is noteworthy that the names of the Yakut etymology prevail among the oykonyms and oronyms, while the names of the Turkic etymology dominate among the hydronyms and island names (with absence of the Yakut-origin names).

\section{Oykonym (Settlements) - 90}

1) Mongol etymology $-2.2 \%$ 
2) Turkic etymology $-20 \%$

3) Tungus etymology $-3.3 \%$

4) Yakut etymology $-41 \%$

5) Russian etymology $-5.5 \%$

6) Mixed etymology $-4.4 \%$

7) Unknown etymology $-23.3 \%$

Hydronyms (Lakes - 45, rivers - 140) - 185

1) Mongol etymology $-11.3 \%$

2) Turkic etymology $-50 \%$

3) Tungus etymology $-2.1 \%$

4) Yakut etymology - 0\%

5) Russian etymology - 1\%

6) Mixed etymology $-20 \%$

7) Unknown etymology $-15.6 \%$

\section{Oronym (Location relief) - 32}

1) Mongol etymology $-0 \%$

2) Turkic etymology $-18.7 \%$

3) Tungus etymology $-6.2 \%$

4) Yakut etymology - $28 \%$

5) Russian etymology $-3.1 \%$

6) Mixed etymology - 19\%

7) Unknown etymology $-25 \%$

\section{Island names -43}

1) Mongol etymology $-9.3 \%$

2) Turkic etymology $-53.5 \%$

3) Tungus etymology $-2.3 \%$

4) Yakut etymology - 0\%

5) Russian etymology $-2.3 \%$

6) Mixed etymology - $28 \%$

7) Unknown etymology $-4.6 \%$

In total, among the analyzed toponyms (350) of the Khangalassky region:

1) Mongol etymology $-7.7 \%$

2) Turkic etymology $-39.7 \%$

3) Tungus etymology $-2.8 \%$

4) Yakut etymology $-13.2 \%$ 
5) Russian etymology $-2.6 \%$

6) Mixed etymology $-16.9 \%$

7) Unknown etymology $-17.1 \%$

Based on the etymology and historical assumptions one can note that settlements predominantly appear later, when intensive economic development occurs among the Yakuts, and with the arrival of the Russians. This is reflected in the names of the settlements. Oykonyms are mostly of the Yakut origin with the exception of some settlements like Pokrovsk, Chkalov, Chapayevo; or they represent an assimilation of the Evenki and the Yakut words by Russian, like in the names of Sinsk, Kachikatsy, or names of mixed etymology, like the Verkhny (Upper) Bestyakh.

\section{Conclusion}

Our research allows us to note that etymological and semantic elements of toponymy show that the Khangalassky region's toponymy forms the most ancient layer in the formation of the Yakutia toponymy. Firstly, this could be explained by the region's historical past. It is suggested that the Turkic-language tribes re-located in the territory of the present-day Yakutia in several "waves", the latest of which occurred in the $14^{\text {th }}-15^{\text {th }}$ centuries. The Yakuts as an ethnic group had been formed in the Middle Lena basin on the valleys of Erkeni and Samartai. Here the formation of the ethnic group was finalized on the basis of the mixture between the newcoming Turkic-speaking tribes with the local Paleo Asiatic groups, as well as with the newcoming Mongol-speaking Khoro and Tungus tribes. Secondly, according to the etymological studies, the stage-based character of the toponymic formation in relation to the landscape is revealed.

The first stage is marked by the archetypical names based on the dialectal relations with the nature. Traces of the Tungus-Manchurian tribes of the most ancient layer remained in the names of small rivers and creeks, since the tribes used to move in search of fowl while using large objects as landmarks (mostly along the creeks of Degiletti, Dyangykh, Negyurchene, Siine, Ederge, Edini, Kirim, Keteme, Kycha, Nyuolla, Nachabyl, Oldokun, etc.). During the course of the toponymic formation on the Yakut basis one may observe a layer of the Mongol toponyms (Byrdjangaya, Byryi-Chyna, Bytyrystakh (with Yakut affix), Daban, Dardagar, Dyulyung-Yuryakh, Yedey, Kullaty (Kuldaty), etc.) which had formed before the Turkic toponymic layer (Kenkeme, Kyuryun, Kurunakh, Kyra-Tas, Kyukkyuryui, Kyumyuk-Yuryakh, Kyuryulyur, Left Satagay). These outerlinguistic factors were reflected in the formation of the toponymy of the given uluses. The Khangalassky 
region's toponymy is based on the archetypical, classic type of names, on the dialectal attitude towards nature and its reclamation as strategically necessitated for the livelihood of the people (the Sakha family groups) who had settled in the Middle Lena basin. At the given stage the Lena river as well as adjoining small rivers had played a big part in forming the toponymy of the Tungus-Manchurian, Mongol, and Turkic layers.

The second stage shows the territorial reclamation and their utilization for the benefit of the economic activity. The latest toponymic layers based on the Yakut language as well as the Russian layer have appeared with the settlements. They are marked by a different attitude towards the region's landscape determined by the complete exploration of the territories and their use for the benefit of the economy and strategies of economic utilization.

Thus, the etymological study of the toponyms conducted in one of the regions of the Central Yakutia allows to reveal some regional patterns of the toponymic landscape which have pre-determined a particular set of regularity in naming of the geographical objects, as well as the ontological exploration pattern of the given space.

\section{References}

Barashkov, V.F. Po sledam geograficheskikh nazvanii Ulianovskoy oblasti [Following the traces of geographical names of the Ulyanovskaya oblast], available at: http://ulrgo.ru/region/elibrary/books/Barashkov_V._F._Po_sledam_geograficheskih_ nazvaniy_Ulyanovskoy_oblasti.pdf (accessed 15 October 2018).

Calvo-Iglesias, M.S., DÍaz-Varela, R.A., MÉndez-MartÍnez, G., Fra-Paleo, U. (2012). Using place names for mapping the distribution of vanishing historical landscape features: The Agras field system in northwest Spain. In Landscape Research. 37(4), 501-517. DOI: 10.1080/01426397.2011.604716

Dmitrieva, L.M. (2002). Ontologicheskoe i mentalnoe bytie toponimicheskoi sistemy (na materiale russkoi toponimii Altaia) [Onthological and mental existence of toponymic system (on the material of the Altay Russian toponymy]. Doctoral dissertation... in Philological Sciences, Barnaul, 367 p.

Khokolova, I., Zamorshchikova, L., Filippova, V. (2018). Indigenous place names: the cognitive-matrix analysis. In XLinguaeEuropean Scientific Language Journal 11 (2), 275-291. DOI: 10.18355/XL.2018.11.02.22

Kornev, I.N. (2014) Geografiia i toponimika v kontekste gumanitarnogo diskursa [Geography and toponymy in the context of humanitarian discourse]. In Geograficheskii vestnik [Geographical bulletin], 1 (28), 41-15. 
Rose-Redwood, R., Alderman, D. \& Azaryahu, M. (2010). Geographies of toponymic inscription: New directions in critical place-name studies. In Progress in Human Geography, 34(4), 453-470.

Saneev, G.D., Orlovskaya, M.N., Shevernina, Z.V. (2015). Etimologicheskii slovar’ mongolskikh iazykov [Etymological Dictionary of the Mongol languages]. In Institut vostokovedeniia RAN [Institute of Oriental Studies], 1. - A - E. 224 p.

Saneev, G.D., Orlovskaya M.N., Shevernina Z.V. (2016). Etimologicheskii slovar' mongolskikh iazykov [Etymological Dictionary of the Mongol languages: in 3 volumes]. Institut vostokovedenia RAN [RAS Institute of Oriental Studies], 2, 232p.

Tomakhin, G.D. (1986). Lingvisticheskie aspekty lingvostranovedeniia [Linguistic aspects of linguistic and cultural studies]. In Voprosy iazykoznaniia [Issues of Linguistics], 6, 113-118.

Urazmetova, A.V. (2018). Cognitive peculiarities of toponymic migration (on the material of the USA place names), In Voprosy Kognitivnoy Lingvistiki (2), 140-144.

Vasilyev, V.L. (2006). Slavianskie toponimicheskie drevnosti Novgorodskoi zemli: issledovanie de-antroponimnykh vazvanii na obsheslavianskom fone [Slavic toponymic ancientries of the Novgorod lands: the study of de-anthroponymic names in CommonSlavic context], Doctoral dissertation ... in Philological Sciences, Saint-Petersburg, $551 \mathrm{p}$.

Zamorshchikova, L.S., Gadal, S., Savvinova, A.N., Filippova, V.V., Samsonova, M.V. (2016). Landscape toponymic map: interdisciplinary approach (on the example of Sakha Republic, Russia). $16^{\text {th }}$ International Multidisciplinary Scientific GeoConference SGEM, Albena, Book2, 3, 311-318. DOI: 10.5593/SGEM2016/B23/S11.040

Zhu, Z., Zhang, H., Zhao, J., Guo, X., Zhang, Z., Ding, Y., Xiong, T. (2018). Using toponyms to analyze the endangered Manchu language in Northeast China, In Sustainability, 10(2), available at: https://www.mdpi.com/2071-1050/10/2/563

Zhuchkevich, V.A. (1968). Obshchaia toponimika [General toponymy], Vyssheishaya shkola, $432 \mathrm{p}$. 


\title{
Топонимический ландшафт Центральной Якутии: этимологический анализ географических названий
}

\author{
Л.С. Заморщикова, И.С. Хохолова, \\ А.Н. Иконникова, М.В. Самсонова, \\ В.В. Лебедева
}

Северо-Восточный федеральный университет им. М.К. Аммосова

Россия, 677000, Якутск, ул. Белинского, 58

В статье предпринята попытка реконструкиии освоения территории Центральной Якутии на примере Хангаласского района в разное время разными этническими племенами. На основе этимологического анализа топонимов исследуемой территории выявлены слои этнического влияния, следы, оставленные разными народами в ходе освоения данной территории.

Актуальность данного исследования обусловлена интересом современной географической науки, в частности гуманитарной географии, к взаимоотношению человека и среды, к проблемам онтологии ландшафта как источника широкого спектра соииогуманитарного знания. Кроме того, вопросы этимологии топонимов в якутском языке, раскрывающей пласты знаний об историческом прошлом народов, находящихся в длительном контакте, проблемы языка и культуры народов или племен, повлиявших на формирование якутского языка, с одной стороны, с другой-диалектных особенностей в пределах одного языка для наименования одних и тех же географических объектов, еще недостаточно разработаны.

Цель данной статьи - выявление этимологической составляющей топонимов Якутии для реконструкиии исторического прошлого в освоении территории Центральной Якутии, определение типов выделения ландшафта разными этносами для образования топонима.

Ведущчим методом к исследованию данной проблемы служит сравнительно-сопоставительный с выявлением этимологической составляющей топонимов, а также метод статистической обработки количественных результатов исследования. Изучены более 300 топонимов на материале базы топонимов Хангаласского улуса Центральной Якутии. Этимология топонима изучается на основе словарной дефиниции на материале, полученном от информантов.

В результате исследования выявлены этимологические составляющце топонимов Центральной Якутии. Выбор Хангаласского улуса в изучении топонимии объясняется историческим прошльм региона, так как якуты $^{l}$ как народность сформировались в бассейне Средней Лены, в долинах Эркэни и Самартай. Окончательное формирование народа саха происходит на основе смешения пришлых тюркоязычных племен с местными палеоазиатскими родами, а также с пришлыми монголоязычными хоринцами и тунгусами. Этимологическая и семантическая составляющие топонимии показывают, что топонимия Хангаласского улуса имеет наиболее древний пласт в образовании топонимии Якутии. В формировании топонимизащии Хангаласского

Yakuts. In free encyclopedia "Wikipedia". Available at: https://ru.wikipedia.org/wiki/Якуты 
улуса основную роль сыграла река Лена и прилегающие к ней речки, ручьи, наименования которых мы находим в лингвокультурных пластах, эвенкийском, монгольском, тюркском. В формировании топонимии на основе якутского языка наблюдается пласт монгольских топонимов, который появляется раньше пласта тюркских топонимов. Следы тунгусо-маньчжурских племен наиболее древнего пласта в названиях речек, ручьев, так как они кочевали в поисках промысла и при этом на крупные объекты. Наиболее поздним пластом считаются топонимы русской этимологии, связанные с освоением территории исследуемого района русскими землепроходиами и поселением на землях Хангаласского улуса переселенных крестьян, почтовым трактом - связуюшим звеном Якутского края с Российской империей во времена иарствований Петра I и Екатерины II.

Исследование показывает поэтапность формирования топонимов по отнотению к ландшафту, что позволяет систематизировать происхождение топонима в историческом и лингвистическом контексте. Материалы статьи могут быть полезными для лингвистов, историков, культурологов, географов.

Ключевые слова: ландшафт, топонимы, освоение территории, культура, этимология, этнические и языковые контакты.

Данная статья написана в рамках проекта Российского научного фонда № 15-18-20047 «Онтология ландшафта: семантика, семиотика, и географическое моделирование» (2015-2017 22.).

Научная специальность: 24.00.00 - культурология. 